\title{
PENGARUH KOMPENSASI, MOTIVASI DAN KEPUASAN KERJA TERHADAP KINERJA PEGAWAI PADA DINAS PERTANIAN KOTA BIMA
}

\author{
Ichwanul Muslimin \\ Program Pasca Sarjana, Universitas Terbuka \\ Ichwanul.muslimin2017@gmail.com
}

\begin{abstract}
Abstrak
Maju mundurnya suatu organisasi sangat ditentukan oleh keberadaan pegawai yang memiliki kualitas dan integritas kerja pegawai. Pegawai berkerja dengan baik sesuai dengan standar yang ditetapkan memiliki alasan terutama masalah kompensasi, motivasi dan kepuasan kerja. Tujuan penelitian ini adalah untuk menganalisis pengaruh kompensasi, motivasi dan kepuasan kerja terhadap kinerja pegawai pada Dinas Pertanian Kota Bima. Sampel dalam penelitian ini adalah seluruh pegawai Dinas Pertanian Kota Bima Berstatus Negeri berjumlah 90 orang. Instrumen penelitian ini adalah menggunakan kuesioner dan sebelum instrument digunakan dilakukan uji validitas dan reliabilitas instrument. Data dianalisis dengan menggunakan regresi berganda. Hasil analisis regresi menggunakan SPSS for windows diketahui bahwa kompensasi, motivasi dan kepuasan kerja berpengaruh signifikan terhadap kinerja pegawai. Kemudian setelah dilakukan analisis stepwisse diketahui bahwa kepuasan kerja merupakan variable yang paling dominan dalam mempengaruhi kinerja pegawai. Oleh karena itu langkah yang paling penting dilakukan oleh Pemerintah Kota Bima terutama Dinas Pertanian adalah meningkatkan kepuasan kerja pegawai dengan memperhatikan pemberian kompensasi dan motivasi kerja pegawai.
\end{abstract}

Kata Kunci: Kinerja, Kompenasi, Motivasi dan Kepuasan Kerja

\section{PENDAHULUAN}

Dinas Pertanian Kota Bima memiliki visi yaitu terwujudnya pembangunan pertanian tanaman pangan dan peternakan yang maju dan efisien menuju masyarakat Kota Bima yang sejahtera. Untuk mewujudkan visi dimaksud, maka misi yang diembannya maka harus ada upaya nyata dalam meningkatkan pemanfaatan sumber daya pertanian dan pemberdayaan masyarakat dalam mengembangkan usaha pertanian melalui pengembangan sarana dan prasarana, penerapan teknologi serta menumbuhkembangkan usaha-usaha agribisnis pertanian dalam upaya meningkatkan kesejahteraan masyarakat dan peningkatan hasil produk pangan segar dan olahan yang aman, sehat, utuh dan halal (ASUH) dikonsumsi.

Untuk mencapai visi di Dinas Pertanian maka dibutuhkan kualitas kerja dari masingmasing pegawai yang bertugas di Dinas Pertanian, karena semakin baik dan berkualitas kerja pegawai secara keseluruhan maka semakin baik pula kinerjanya. Laporan Kinerja Instansi Pemerintah (LAKIP) Dinas Pertanian Kota Bima menjadi cerminan untuk mengetahui sejauhmana capaian kinerja pegawainya. LAKIP Dinas Pertanian Kota Bima Tahun 2019 mengindikasikan bahwa kinerja pegawai Dinas Pertanian masih banyak yang harus ditingkatkan lagi dengan tidak menafikan banyak yang telah tercapai sebagaimana yang terlihat dalam tabel di bawah ini.

Tabel 1. Pengukuran Capaian Kinerja Dinas Pertanian Tahun 2019

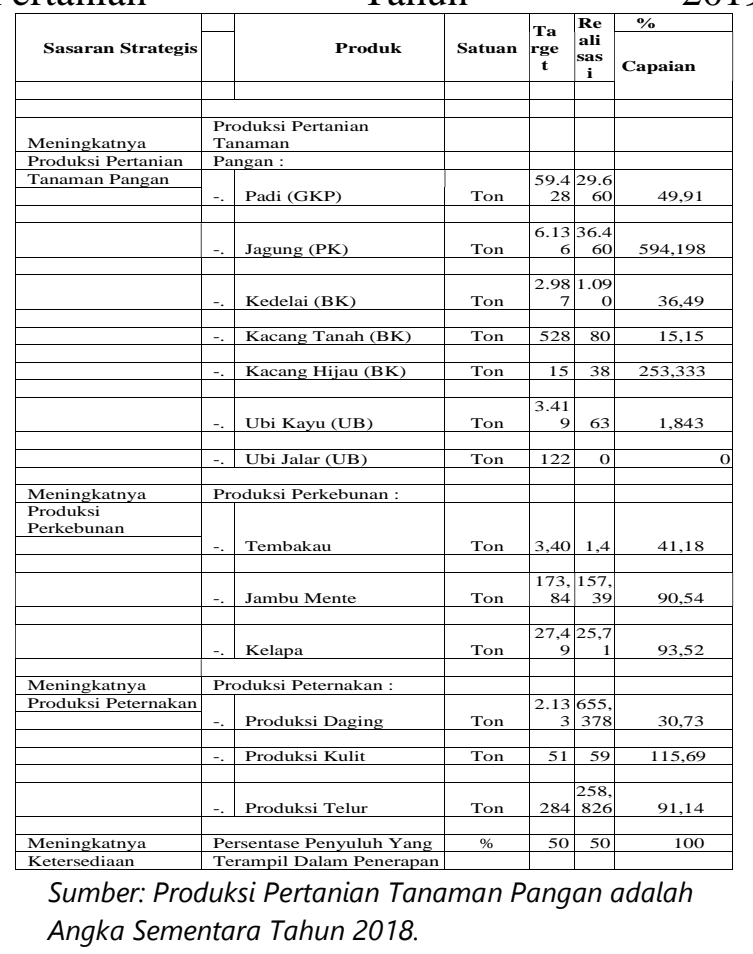


Tabel 1 dapat dijelaskan bahwa beberapa indikator kinerja Produksi Pertanian Tanaman Pangan belum mencapai target sebagaimana yang telah ditentukan sebelumnya dimana ratarata sebesar 81,049\%, tapi untuk komoditi jagung dan kacang hijau produksinya diatas $100 \%$ sedangkan untuk komoditi lainnya seperti padi, kedelai, kacang tanah, ubi kayu dan ubi jalar produksinya dibawah target, hal ini disebabkan oleh besarnya animo masyarakat untuk menanam komoditi jagung yang dikarenakan oleh harganya yang menjanjikan dan adanya program nasional dalam mendukung peningkatan produksi jagung, untuk produksi padi yang sebesar 21.860 ton dalam kaitannya dengan pemenuhan kebutuhan beras masyarakat masih terjadi surplus sebesar 4.719,63 ton dengan asumsi rata-rata konsumsi perkapita/pertahun sebesar 114,6 $\mathrm{kg} / \mathrm{kapita} /$ tahun (Biro Humas dan Informasi Publik Kementan RI Tanggal 28 September 2017) dan jumlah penduduk Kota Bima sebesar 149.567 jiwa. Pada 2018,

Pemerintah Propinsi NTB mencanangkan target produksi padi menembus 1,40 juta ton. Dari target itu, produksi sampai bulan September hanya mencapai 1,31 juta ton, dengan luas lahan tanam dicanangkan seluas 281.010 hektar. Dari target tersebut, Pemerintah Kota Bima melalui Dinas Pertanian Kota Bima menyumbang produksi padi sebesar 21.860 ton atau sebesar 1,67\%.

Kinerja pegawai adalah suatu hal yang harus diperhatikan oleh organisasi karena kinerja pegawai menentukan kinerja organisasi (Wirawan, 2009:9). Oleh karena itu untuk tetap dapat mempertahankan serta meningkatkan pelayanan publik dan produktifitas pada saat ini, dinas pertanian harus memperhatikan kinerja para pegawainya.

Fenomena yang terjadi di dinas pertanian antara lain pegawai merasa kurang puas dengan kompensasi yang diterima, dalam hal ini terkait masalah tunjangan yang dirasa masih kurang memadai. Kompensasi berupa tunjangan ini diberikan untuk meningkatkan motivasi dan kepuasan kerja pegawai agar dalam pelaksanaan tugasnya pegawai tidak ada alasan lagi tidak bekerja dengan rajin sehingga memiliki kinerja yang baik. Kompensasi juga dipandang dalam kaitannya dengan ketepatan dan kelancaran waktu membayar kompensasi karena sering terjadi keterlambatan pembayaran kompensasi sehingga menjadi masalah yang cukup serius yang berdampak produktivitas kerja. Fenomena lain adalah pegawai merasa kesempatan untuk promosi dirasa masih kurang, karena peluang promosi yang sempit menjadi kendala yang menghambat pegawai untuk terus maju melangkah meniti karirnya sebab promosi juga menjadi bagian dari kompensasi non materi. Penelitian Suwati (2013) menyimpulkan pemberian kompensasi dapat mempengaruhi kinerja karyawan. Akan tetapi berbeda dengan hasil penelitian Gelard (2016) bahwa kompensasi memiliki pengaruh yang tidak signifikan terhadap kinerja karyawan.

Observasi peneliti berkaitan dengan motivasi adalah bahwa ada beberapa oknum pegawai menganggap pekerjaan hanyalah rutinitas sehingga dalam bekerja kurang bersemangat. Selain itu ada beberapa pegawai yang merasa kurang mendapatkan pengakuan atau penghargaan dari atasan atas hasil pekerjaannya padahal mereka sudah menyelesaikan pekerjaan tersebut dengan baik. Selain itu peneliti melihat dalam hal kepuasan kerja terkait sarana kerja seperti ruangan kerja yang kurang layak karena sempit dan bangunannya terlihat rusak. Selain itu, terkait komputer dan laptop serta software yang digunakan oleh pegawai sudah usang sehingga pegawai merasa tidak nyaman dalam bekerja.

Penelitian lain menemukan bahwa motivasi kerja memiliki peranan penting dalam menentukan baik atau buruknya kinerja pegawai. Pegawai yang memiliki motivasi kerja yang tinggi akan selalu memiliki semangat kerja, inisiatif dan ulet dalam menyelesaikan setiap bidang tugasnya serta akan selalu berupaya untuk mencarikan solusinya sehingga memiliki kualitas kerja yang tinggi. Wardoyo dan Priyono (2015) menyimpulkan untuk meningkatkan kinerja perlu memperhatikan motivasi kerja dari para karyawan. Penelitian Saranya (2014) dan Rindiantika dan Heru (2018) motivasi memiliki 
pengaruh terhadap kinerja. Demikian hasil penelitian Katua (2014) menilai bahwa dalam mencapai cita-cita besar dalam organisasi motivasi kerja anggota sangat penting untuk diperhatikan dan ditingkatkan karena akan berdampak langsung dengan kinerja dan produktivitas pegawai. Namun berbeda dengan Munandar (2016) bahwa motivasi tidak memilik pengaruh signifikan terhadap kinerja.

Kompensasi dan motivasi tidak lengkap tanpa memperhatikan kepuasan kerja pegawai. Kepuasan kerja dapat menentukan sikap pegawai terhadap pekerjaannya. Ilahi dan Mukzam (2017) kepuasan kerja menjadi sangat urgen karena menyangkut perasaanperasaan positif tentang pekerjaan tersebut, sementara seseorang yang tidak puas memiliki perasaan-perasaan yang negative terhadap pekerja yang berdampak pada kinerja. Pitasari dan Perdhana (2018) menyimpulkan pegawai yang tidak memperoleh kepuasan kerja tidak akan pernah mencapai kepuasan psikologis dan akhirnya akan timbul sikap atau tingkah laku negatif dan dapat menimbulkan frustasi. Sebaliknya pegawai yang terpuaskan akan bekerja dengan baik,

penuh semangat, aktif dan dapat berprestasi pada gilirannya akan menurunkan kinerja. Altahtooh (2018) menemukan bahwa kepuasan kerja menjadi fokus kebijakan peningkatan produktivitas kerja karyawan. Dengan kata lain kepuasan kerja memiliki pengaruh terhadap kinerja. Berbeda dengan hasil penelitian Abidin (2013) dan Agung (2013) bahwa kepuasan kerja tidak berpengaruh signifikan terhadap kinerja. Orang merasa puas terhadap kebijakan organisasi tidak secara otomatis dapat bekerja dengan baik sesuai dengan tuntutan dan target organisasi.

Penjelasan di atas peneliti merasa berkepentingan untuk telibat secara akademik dengan meneliti "Pengaruh Kompensasi, Motivasi dan Kepuasan Kerja Terhadap Kinerja Pegawai Dinas Pertanian Kota Bima” dengan tujuan:

1. Menganalisis pengaruh kompensasi terhadap kinerja pegawai Dinas Pertanian Kota Bima
2. Menganalisis pengaruh motivasi kerja terhadap kinerja pegawai Dinas Pertanian Kota Bima

3. Menganalisis pengaruh kepuasan kerja terhadap kinerja pegawai Dinas Pertanian Kota Bima

4. Menganalisis variabel yang berpengaruh dominan terhadap terhadap kinerja pegawai Dinas Pertanian Kota Bima.

\section{KAJIAN PUSTAKA Kinerja Pegawai}

Menurut Marwansyah (2012) kinerja atau unjuk kerja adalah pencapaian atau prestasi seseorang berkenaan dengan tugastugas yang diberikan kepedanya. Adapun pengertian kinerja Menurut Rivai, et. al (2009), kinerja merupakan hasil atau tingkat keberhasilan seseorang secara keseluruhan selama periode tertentu di dalam melaksanakan tugas dibandingkan dengan berbagai kemungkinan, seperti standar hasil kerja, target atau sasaran atau kriteria yang telah ditentukan terlebih dahulu dan telah disepakati bersama. Menurut Notoatmodjo (2009), kinerja adalah apa yang dapat dikerjakan oleh seseorang sesuai dengan tugas dan fungsinya. Faktor-faktor yang mempengaruhi pencapaian kinerja karyawan adalah factor kemampuan (ability) dan motivasi (motivation).

Menurut Robins dan Judge (2008) ada beberapa indikator untuk mengukur kinerja seseorang yaitu: (1) Kualitas kerja diukur dari persepsi karyawan terhadap kualitas pekerjaan yang dihasilkan serta kesempurnaan tugas terhadap keterampilan dan kemampuan pegawai.

(2) Kuantitas kerja merupakan jumlah yang dihasilkan dinyatakan dalam istilah seperti jumlah unit, jumlah siklus aktivitas yang diselesaikan. (3) Ketepatan waktu adalah tingkat aktivitas diselesaikan pada awal waktu yang dinyatakan, dilihat dari sudut koordinasi dengan hasil output serta memaksimalkan waktu yang tersedia untuk aktivitas lain. (4) 
Efektivitas merupakan tingkat penggunaan sumber daya organisasi (tenaga, uang, teknologi, bahan baku) dimaksimalkan dengan maksud menaikkan hasil dari setiap unit dalam penggunaan sumber daya. (5) Kemandirian merupakan tingkat seorang karyawan yang nantinya akan dapat menjalankan fungsi kerjanya komitmen kerja. Merupakan suatu tingkat dimana karyawan mempunyai komitmen kerja dengan instansi dan tanggung jawab karyawan terhadap kantor.

\section{Kompensasi Kerja}

Kompensasi adalah semua pendapatan yang berbentuk uang, barang langsung atau tidak langsung yang diterima pegawai sebagai imbalan atas jasa yang diberikan kepada perusahaan (Hasibuan, 2010). Kompensasi merupakan pengeluaran dan biaya bagi perusahaan.Perusahaan mengharapkan agar kompensasi yang dibayarkan memperoleh kompensasi prestasi kerja yang lebih besar dari karyawan. Jadi, nilai prestasi kerja karyawan

harus lebih besar dari kompensasi yang dibayar perusahaan, supaya perusahaan mendapatkan laba dan kontinuitas perusahaan terjamin.Jelaslah pentingnya masalah kompensasi ini untuk karyawan dan perusahaan. Menurut Luthan (2011) kompensasi atau imbalan merupakan total seluruh kompensasi yang diterima karyawan sebagai pengganti jasa mereka. Sedangkan menurut Rivai dan Sagala (2009:741), kompensasi merupakan sesuatu yang diterima pegawai sebagai pengganti kontribusi jasa mereka pada perusahaan.Menurut Flippo dalam Hasibuan (2010:119), Upah didefinisikan sebagai balas jasa yang adil dan layak diberikan kepada para pekerja atas jasajasanya dalam mencapai tujuan organisasi. Menurut Sikula (dalam Hasibuan, 2010:119), kompensasi adalah segala sesuatu yang dikonstitusikan atau dianggap sebagai suatu balas jasa atau ekuivalen.

Menurut Rivai dan Sagala (2009:744), komponen-komponen kompensasi terdiri dari:

(1) Gaji adalah balas jasa dalam bentuk uang yang diterimapegawai sebagai konsekuensi dari kedudukannya sebagai seorang pegawai yang memberikan sumbangan tenaga dan pikiran dalam mencapai tujuan perusahaan; (2) Upah merupakan kompensasi financial langsung yang dibayarkan pada pegawai berdasarkan jam kerja, jumlah barang yang dihasilkan atau banyaknya pelayanan yang diberikan; (3) Insentif merupakan Kompensasi langsung yang dibayarkan kepada pegawai karena kinerjanya melebihi standar yang ditentukan. Insentif merupakan Fenomena yang terjadi di dinas pertanian antara lain pegawai merasa kurang puas dengan kompensasi yang diterima, dalam hal ini terkait masalah tunjangan yang dirasa masih kurang memadai. Kompensasi berupa tunjangan ini diberikan untuk meningkatkan motivasi dan kepuasan kerja pegawai agar dalam pelaksanaan tugasnya pegawai tidak ada alasan lagi tidak bekerja dengan rajin sehingga memiliki kinerja yang baik. Kompensasi juga dipandang dalam kaitannya dengan ketepatan dan kelancaran waktu membayar kompensasi karena sering terjadi keterlambatan pembayaran kompensasi sehingga menjadi masalah yang cukup serius yang berdampak produktivitas kerja. Fenomena lain adalah pegawai merasa kesempatan untuk promosi dirasa masih kurang, karena peluang promosi yang sempit menjadi kendala yang menghambat pegawai untuk terus maju melangkah meniti karirnya sebab promosi juga menjadi bagian dari kompensasi non materi. Penelitian Suwati (2013) menyimpulkan pemberian kompensasi dapat mempengaruhi kinerja karyawan. Akan tetapi berbeda dengan hasil penelitian Gelard (2016) bahwa kompensasi memiliki pengaruh yang tidak signifikan terhadap kinerja karyawan.

Observasi peneliti berkaitan dengan motivasi adalah bahwa ada beberapa oknum pegawai menganggap pekerjaan hanyalah rutinitas sehingga dalam bekerja kurang bersemangat. Selain itu ada beberapa pegawai yang merasa kurang mendapatkan pengakuan atau penghargaan dari atasan atas hasil pekerjaannya padahal mereka sudah menyelesaikan pekerjaan tersebut dengan baik. Selain itu peneliti melihat dalam hal kepuasan kerja terkait sarana kerja seperti ruangan kerja yang kurang layak karena sempit 
dan bangunannya terlihat rusak. Selain itu, terkait komputer dan laptop serta software yang digunakan oleh pegawai sudah usang sehingga pegawai merasa tidak nyaman dalam bekerja.

Penelitian lain menemukan bahwa motivasi kerja memiliki peranan penting dalam menentukan baik atau buruknya kinerja pegawai. Pegawai yang memiliki motivasi kerja yang tinggi akan selalu memiliki semangat kerja, inisiatif dan ulet dalam menyelesaikan setiap bidang tugasnya serta akan selalu berupaya untuk mencarikan solusinya sehingga memiliki kualitas kerja yang tinggi. Wardoyo dan Priyono (2015) menyimpulkan untuk meningkatkan kinerja perlu memperhatikan motivasi kerja dari para karyawan. Penelitian Saranya (2014) dan Rindiantika dan Heru (2018) motivasi memiliki pengaruh terhadap kinerja. Demikian hasil penelitian Katua (2014) menilai bahwa dalam mencapai cita-cita besar dalam organisasi motivasi kerja anggota sangat penting untuk diperhatikan dan ditingkatkan karena akan berdampak langsung dengan kinerja dan produktivitas pegawai. Namun berbeda dengan Munandar (2016) bahwa motivasi tidak memilik pengaruh signifikan terhadap kinerja.

Kompensasi dan motivasi tidak lengkap tanpa memperhatikan kepuasan kerja pegawai. Kepuasan kerja dapat menentukan sikap pegawai terhadap pekerjaannya. Ilahi dan Mukzam (2017) kepuasan kerja menjadi sangat urgen karena menyangkut perasaanperasaan positif tentang pekerjaan tersebut, sementara seseorang yang tidak puas memiliki perasaan-perasaan yang negative terhadap pekerja yang berdampak pada kinerja. Pitasari dan Perdhana (2018) menyimpulkan pegawai yang tidak memperoleh kepuasan kerja tidak akan pernah mencapai kepuasan psikologis dan akhirnya akan timbul sikap atau tingkah laku negatif dan dapat menimbulkan frustasi. Sebaliknya pegawai yang terpuaskan akan bekerja dengan baik, penuh semangat, aktif dan dapat berprestasi pada gilirannya akan menurunkan kinerja. Altahtooh (2018) menemukan bahwa kepuasan kerja menjadi fokus kebijakan peningkatan produktivitas kerja karyawan. Dengan kata lain kepuasan kerja memiliki pengaruh terhadap kinerja.
Berbeda dengan hasil penelitian Abidin (2013) dan Agung (2013) bahwa kepuasan kerja tidak berpengaruh signifikan terhadap kinerja. Orang merasa puas terhadap kebijakan organisasi tidak secara otomatis dapat bekerja dengan baik sesuai dengan tuntutan dan target organisasi.

bentuk lain dari upah langsung diluar upah dan gaji yang merupakan kompensasi tetap, yang biasa disebut kompensasi berdasarkan kinerja (pay for performance plan); (4) Kompensasi tidak langsung (Faringe Benefit). Fringe Benefit merupakan kompensasi tambahan yang diberikan berdasarkan kebijakan perusahaan terhadap semua pegawai sebagai upaya meningkatkan kesejahteraan para pegawai. Contohnya, berupa fasilitas-fasilitas, seperti; asuransiasuransi, tunjangan- tunjangan, uang pensiun, dan lain-lain.

\section{Motivasi Kerja}

Motivasi merupakan suatu konsep yang bersifat penjelasan tentang memahami perilaku yang diamati. Alasan utama mengapa perilaku karyawan berbeda-beda adalah bahwa kebutuhan dan tujuan orang bervariasi.Teori motivasi memberi perhatian pada perilaku yang diarahkan pada tujuan.Sejumlah teori motivasi yang populer, diuji secara empiris dan praktis, seperti teori hirarki kebutuhan Maslow, teori ERG Alderfer, teori dua faktor Herzberg, dan teori kebutuhan (Mangkunegara (2010). Masing-masing teori mencoba mengorganisir, dalam suatu cara yang bermakna, dan bisa membantu manajer atau pimpinan lebih memahami motivasi area kerja. Sunarto (2013:43) mengatakan bahwa motivasi kerja sebagai perilaku yang berorientasi tujuan. Secara umum cara untuk memotivasi pegawai adalah dengan memberikan insentif, imbalan, kesempatan untuk pembelajaran dan pertumbuhan serta jenjang karir yang cukup menjanjikan bagi kehidupan di masa yang akan

datang. Dalam konteks ini bahwa motivasi kerja menjadi pendorong seseorang melaksanakan suatu kegiatan guna mendapat hasil yang terbaik. 
Kadarisman (2012) mangatakan pekerjaan yang dilakukan oleh seorang manajer dalam memberikan inspirasi, semangat dan dorongan kepada orang lain, dalam hal ini karyawannya untuk mengambil tindakan-tindakan. Alvio dan Endang, (2017:168) menyebut bahwa teori ERG dikemukakan oleh Clayton Alderfer seorang psikolog asal Amerika Serikat, 1940.Teori ini merupakan simplifikasi dan pengembangan lebih lanjut dari teori hirarki kebutuhan Abraham Maslow. Untuk mengukur motivasi (1) Motivasi untuk berprestasi; (2) Motivasi untuk berkuasa; dan (3) Motivasi untuk berafilianasi kerja (Robbins, 2008).

\section{Kepuasan Kerja}

Anoraga (2006) mengungkapkan bahwa kepuasan kerja merupakan suatu sikap yang positif yang menyangkut penyesuaian diri yang sehat dari para pegawai terhadap kondisi dan situasi kerja, termasuk didalamnya masalah upah, kondisi sosial, kondisi fisik dan kondisi psikologis. Sedangkan menurut Kreitner dan Kinicki (2005)

kepuasan kerja merupakan suatu efektivitas atau respons emosional terhadap berbagai aspek pekerjaan. Prawironegoro dan Siswandoko (2011) juga mendefinisikan kepuasan kerja sebagai seperangkat perasaan pegawai yang menyenangkan atau yang tidak menyenangkan berdasarkan imbalan material dan imbalan psikologis (non- material). Kepuasan kerja sebagai suatu perasaan positif tentang pekerjaan seseorang yang merupakan hasil dari sebuah avaluasi karakteristiknya. Pendekatan ini mendefinisikan elemen-elemen penting dalam suatu pekerjaan dan menanyakan perasaan pegawai tentang setiap elemen. Faktor-faktor khusus yang akan dimasukkan adalah sifat pekerjaan, pengawasan, bayaran saat ini, peluang promosi, dan hubungan dengan rekan-rekan kerja (Robbins dan Judge, 2008:107). Handoko (2011:157) memaknai kepuasan kerja sebagai keadaan emosional yang menyenangkan dengan mana para karyawan memandang pekerjaan mereka.Kepuasan kerja mencerminkan perasaan seseorang terhadap pekerjaannya.Ini nampak dalam sikap positif karyawan terhadap pekerjaan dan segala sesuatu yang dihadapi di lingkungan kerja.

Indikator kepuasan kerja yang dipakai peneliti adalah indikatorindikator yang dikembangkan oleh Celluci dikutip Mas'ud (2009) yang meliputi antara lain: (1) Kepuasan terhadap gaji, yaitu senang atau tidak senang karyawan akan gaji yang diterima. (2) Kepuasan dengan promosi, yaitu sikap senang atau tidak senang karyawan akan promosi yang dilakukan perusahaan. (3) Kepuasan terhadap rekan kerja, yaitu sikap senang atau tidak senang karyawan akan dukungan dari rekan kerjanya. (4) Kepuasan terhadap supervisor, yaitu sikap senang atau tidak senang karyawan akan perlakuan dari pimpinan.

\section{METODE PENELITIAN}

Penelitian ini merupakan penelitian kuantitatif yang menggunakan jenis penelitian asosiatif yang mencari hubungan antara satu variabel dengan variabel lain. Hubungan yang digunakan adalah hubungan kausal yang bersifat sebab akibat. Hubungan yang digunakan dalam penelitian ini adalah hubungan kausal (sebab- akibat) variabel kompensasi, motivasi kerja dan kepusaan kerja terhadap kinerja pegawai. Populasi penelitian adalah seluruh pegawai pada Dinas Pertanian Kota Bima sebanyak 124 orang terdiri dari 90 orang yang bestatus negeri dan 34 orang yang berstatus sebagai pegawai honorer dan yang dijadikan sampel penelitian sebanyak 90 orang. Instrumen penelitian adalah kuesioner dengan menggunakan skala likert. Data dianalisis dengan menggunakan analisis regresi linier berganda dengan model persamaan regresi sebagai berikut:

$\mathrm{Y}=\mathrm{a}+\mathrm{b} \times 1+\mathrm{b} \times 2+\mathrm{b} \times 3+\mathrm{e}$

Keterangan:

$\mathrm{Y}=$ Kinerja Pegawai a

$\mathrm{a}=$ Kontan

bx1 = Kompensasi

bx2 = Motivasi Kerja

bx3 = Kepuasan Kerja 


\section{HASIL PENELITIAN Analisis Deskkriptif}

Hasil analisis deskriptif menunjukkan bahwa rata-rata memberi penilaian mengenai kompensasi berada pada kategori cukup, yaitu 71 orang atau $79 \%$, ada 15 orang atau $17 \%$ berada pada kategori sangat tinggi dan yang paling sedikit berada pada kategori rendag yaitu 4 orang atau $4 \%$. Kemudian variabel motivasi kerja menunjukkan bahwa rata-rata memberi penilaian mengenai motivasi kerja berada pada kategori tinggi, yaitu 58 orang atau $64 \%$, ada 32 orang atau $36 \%$ berada pada kategori sangat tinggi. Kepuasan kerja menunjukkan bahwa rata- rata atau sebanyak 58 orang atau $64 \%$ memiliki kepuasan kerja yang tergolong tinggi dan sebanyak 32 orang atau $36 \%$ berada pada kategori sangat tinggi. Hasil analisis deskriptif tentang kinerja pegawai menunjukkan bahwa rata-rata kinerja pegawai berpada kategori tinggi, yaitu 56 orang atau $62 \%$, dan 34 orang atau $38 \%$ berada pada kategori sangat tinggi.

\section{Analisis Regresi}

Adapun hasil analisis regresi berganda mengenai pengaruh parsial masing- masing variabel bebas terhadap variabel terikat yang dapat dilihat pada tabel yaitu sebagai berikut:

Tabel 2 Regresi Pengaruh Parsial Variabel Bebas (X) terhadap Variabel Terikat (Y)

\begin{tabular}{|c|c|c|c|c|c|c|}
\hline \multirow[b]{2}{*}{ Model } & & $\begin{array}{r}\mathbf{C c} \\
\begin{array}{r}\text { Unstanda } \\
\text { Coeffic }\end{array} \\
\end{array}$ & $\begin{array}{l}\text { effici } \\
\text { addized } \\
\text { ients }\end{array}$ & $\begin{array}{l}\mathbf{n t s}^{\mathbf{a}} \\
\text { Standardized } \\
\text { Coefficients } \\
\end{array}$ & & \\
\hline & & B & Std. Error & $\frac{\text { Coefficients }}{\text { Beta }}$ & $\mathrm{t}$ & Sig. \\
\hline \multirow[t]{4}{*}{1} & (Constant) & 10.049 & 3.006 & & 3.343 & .001 \\
\hline & Kompensasi Kerja & .491 & .102 & .456 & 4.810 & .000 \\
\hline & Motivasi Kerja & .490 & .078 & .558 & 6.306 & .000 \\
\hline & Kepuasan Kerja & .677 & .071 & .713 & 9.531 & .000 \\
\hline
\end{tabular}

a. Dependent Variable: Kinerja Pegawai

\section{Persamaan Regresi:}

$' \mathrm{Y}=\alpha(10.049)+\beta 1 \mathrm{X} 1(0.456)+\beta 2 \mathrm{X} 2$ $(0.558)+\beta 3$ X3 (0.713)

\begin{tabular}{|c|l|}
\hline \multicolumn{1}{|c|}{} & Tabel 3 Penjelasan Persamaan Regresi \\
\hline \multicolumn{1}{|c|}{ Simbol } & \\
\hline$\alpha$ & Mengisyaratkan bahwa jika tidak ada kompensasi, motivasi dan \\
\hline \hline & kepuasan kerja dalam pelaksanaan tugas maka kinerja pegawai \\
\hline \hline$\beta_{1} \mathrm{X}_{1}$ & Mengisyaratkan bahwa jika kompensasi kerja bergeser sebesar \\
\hline & satu saja maka akan menggeser kinerja pegawai Dinas Pertanian \\
\hline & Kota Bima sebesar $\mathbf{0 . 4 5 6}$. Artinya besar pengaruh kompensasi \\
\hline & terhadap kinerja pegawai sebesar $\left(\mathbf{0 . 4 5 6}^{2} \times \mathbf{1 0 0}\right)=21 \%$ dan \\
\hline & sisanya dipengaruhi oleh variable lain. \\
\hline$\beta_{2} \mathrm{X}_{2}$ & Mengisyaratkan bahwa jika motivasi kerja bergeser sebesar satu \\
\hline & saja maka akan menggeser kinerja pegawai Dinas Pertanian Kota \\
\hline & Bima sebesar $\mathbf{0 . 5 5 8}$. Artinya besar pengaruh motivasi terhadap \\
\hline & kinerja pegawai sebesar $\left(\mathbf{0 . 5 5 8} \mathbf{2}^{2} \times \mathbf{1 0 0}\right)=31 \%$ dan sisanya \\
\hline$\beta_{3} \mathrm{X}_{3}$ & Mengisyaratkan bahwa jika kepuasan kerja bergeser sebesar satu \\
\hline & saja maka akan menggeser kinerja pegawai Dinas Pertanian Kota \\
\hline
\end{tabular}

Bima sebesar 0.713. Artinya besar pengaruh kepuasan kerja

terhadap kinerja pegawai sebesar $\left(\mathbf{0 . 7 1 3}^{2} \times \mathbf{1 0 0}\right)=51 \%$ dan sisanya dipengaruhi oleh variabel lain.

\section{Analisis Stepwase}

Untuk mengetahui model regresi terbaik dari tiga variabel indepen terhadap variabel dependen maka dilakukan dengan menggunakan analisis stapwase. Regresi Stepwise adalah salah satu metode untuk mendapatkan model terbaik dari sebuah analisis regresi. Variabel yang pertama kali masuk adalah variabel yang korelasinya tertinggi dan significant dengan variabel dependent variabel yang masuk kedua adalah variabel yang korelasi parsialnya tertinggi dan masih significant setelah variabel tertentu masuk ke dalam model maka variabel lain yang ada di dalam model dievaluasi, jika ada variabel yang tidak significant maka variabel tersebut dikeluarkan.

Tabel 4 Ringkasan Hasil Analisis Stepwase

\section{Coefficients $^{\mathrm{a}}$}

\begin{tabular}{|c|c|c|c|c|c|}
\hline \multirow[b]{3}{*}{ Model } & & \multirow{2}{*}{\multicolumn{2}{|c|}{$\begin{array}{l}\text { Unstandardized } \\
\text { Coefficients } \\
\end{array}$}} & \multirow{3}{*}{$\begin{array}{c}\text { Standardized } \\
\text { Coefficients } \\
\text { Beta } \\
\end{array}$} & \multirow[b]{3}{*}{ Sig. } \\
\hline & & & & & \\
\hline & & B & Std. Error & & \\
\hline 1 & (Constant) & 10.049 & 3.006 & & .001 \\
\hline & Kompensasi kerja & .077 & .097 & .072 & .430 \\
\hline & Motivasi kerja & .166 & .085 & .189 & .053 \\
\hline & Kepuasan Kerja & .538 & .088 & .567 & .000 \\
\hline
\end{tabular}

a. Dependent Variable: Kinerja Pegawai

Berdasarkan tabel 4.21 maka dapat ditarik kesimpulan bahwa variabel yang paling kecil taraf signifikan yaitu variable kepuasan kerja yaitu, 0.00 dengan Standardized Coefficients Beta 0,567 sedangan variable kempensasi 0,072 dan sig. 0,43, motivasi kerja 
0,189 dan sig 0,05. Dengan kata lain variabel kepuasan kerja memiliki pengaruh dominan terhadap kinerja pegawai Dinas Pertanian Kota Bima.

\section{Pengujian Hipotesis}

\section{Pengaruh Kompensasi Terhadap Kinerja Pegawai Dinas Pertanian Kota Bima Setelah dilakukan perhitungan diketahui bahwa t-hitung kompensasi sebesar 4.810}

lebih besar dari t-tabel 1.986. Artinya hipotesis nihil (H0) ditolak dan hipotesis alternatif (Ha) yang berbunyi bahwa "Kompensasi Kerja Berpengaruh Positif dan Signifikan Terhadap Kinerja Pegawai Dinas Pertanian Kota Bima”, diterima.

\section{Pengaruh Motivasi Kerja Terhadap Kinerja Pegawai Dinas Pertanian Kota Bima Setelah dilakukan perhitungan diketahui bahwa t-hitung variabel motivasi kerja}

sebesar 6.306 lebih besar dari t-tabel 1,986 dengan taraf signifikan 0,00 . Ini artinya hipotesis nihil (H0) ditolak dan hipotesis alternatif (Ha) yang berbunyi bahwa "Motivasi Kerja Berpengaruh Positif dan Signifikan Terhadap Kinerja Pegawai Dinas Pertanian Kota Bima” dapat diterima.

\section{Pengaruh Kepuasan Kerja Terhadap Kinerja Pegawai Dinas Pertanian Kota Bima Setelah dilakukan perhitungan diketahui bahwa t-hitung variabel kepuasan kerja}

sebesar 9.531 lebih besar dari t-tabel 1.986 dengan taraf signifikan 0,00 lebih kecil dari 0,05 dengan demikian hipotesis nihil (Ha) diterima "Kepuasan Kerja Berpengaruh Positif dan Signifikan Terhadap Kinerja Pegawai Dinas Pertanian Kota Bima".

\section{Pengaruh Dominan Terhadap Kinerja Pegawai Dinas Pertanian Kota Bima}

Setelah melakukan analisis stepwase maka dapat diketahuia bahwa nilai sig. variabel kepuasan kerja memiliki nilai paling rendah yaitu 0,00 dibandingkan dengan variabel kompensasi dan motivasi. Artinya kepuasan kerja memiliki pengaruh paling dominan terhadap kinerja pegawai Dinas Pertanian Kota Bima.

\section{PEMBAHASAN \\ Pengaruh Kompensasi Terhadap Kinerja Pegawai Dinas Pertanian}

Kompensasi pada umumnya diberikan berupa gaji atau tunjangan yang diberikan pada seseorang sebagai balas jasa pekerjaan. Kompensasi juga berkaitan dengan kompensasi

langsung ini dapat berupa bayaran pokok (gaji), bayaran atas prestasi yang telah diberikan pegawai, juga dapat berupa bayaran insentif. Kompensasi finansial tidak langsung berupa tunjangan-unjangan, asuranasi, kesehatan, jugaa fasilitas

lainnya seperti kendaraan, ruang kerja, dan lain-lain diluar gaji pokok, upah, dan bonus. Berbeda dengan kompensasi finansial langsung maupun tidak langsung, kompensasi non finansial ini tidak berupa uang ataupun tunjangan, melainkan kepuasan yang diperoleh oleh pekerja itu sendiri karena lingkungan psikologis dan fisik dari tempat kerjanya. Jadi dapat dipahami kompensasi tidak hanya berupa presolan gaji namun juga menyangkut gaji atau tunjangan semata namun juga menyangkut besar kecilnya, ketepatan waktu dan kelancaran pemberian gaji dan tunjangan kepada pegawai juga merupakan indikator dari kompensasi.

Berkaitan dengan itu, hasil analisis deskriptif diketahui kompensasi pegawai Dinas Pertanian Kota Bima tergolong cukup. Ini menunjukkan bahwa pemberian kompensasi berupa gaji, insentif, dan kelancaran dan ketepatan waktu pemberian kompensasi tergolong cukup baik dan mencukupi pemenuhan kebutuhan dari masing-masing pegawai. Keadaan penting karena akan berdampak kinerja pegawai; pegawai yang memiliki dan mendapat kompensasi yang sesuai denga harapan dan kebutuhan akan lebih rajin, disiplin dan termotivasi untuk lebih giat dalam bekerja 
yang pada gilirannya akan meningkatkan kinerja pegawai.

Hasil pengujian hipotesis penelitian membuktikan kompensasi berpengaruh positif dan signifikan terhadap kinerja pegawai Dinas Pertanian Kota Bima. Dengan kata lain semakin tinggi kompensasi yang diterima akan semakin tinggi pula kinerja pegawai, sebaliknya jika kompensasi yang tidak memadai termasuk tidak adil dalam pemberian kompensasi akan berdampak pada kinerja pegawai. Hasil penelitian

mendukung penelitian sebelumnya dilakukan oleh Rijalu Negash dan Shimelis Zewude (2014) dan Revenio Jalagat (2016) bahwa kompenasisi menjadi alat ukur dan predictor kinerja seseorang. Semakin puas mereka terhadap pemberian kompensasi maka

semakin baik mereka dalam bekerja. Penelitian Pratama dan Hakam (2015) menunjukkan bahwa terdapat pengaruh yang signifikan antara kompensasi finansial dan non finansial terhadap kinerja karyawan PT. Asuransi Jiwasraya (Persero).

Implikasi: Setiap tindakan, kegiatan dan kebijaksanaan pasti dibuat dengan maksud mencapai tujuan tertentu. Demikian pula dalam hal kebijakan kompensasi ini memiliki tujuan tertentu selain tujuan utama organisasi juga terhadap kinerja pegawai. Semakin sesuai kompensasi yang diterima akan mendapatkan hasil kinerja yang maksimal. Selain itu juga kebijakan dalam memberikan kompensasi terhadap pegawai akan menghidarkan dari resiko protes dari pegawai dengan catatan sesuai dengan keinginan dan kebutuhan pegawai. Oleh karena itu, sebagai upaya peningkatan kualitas dan kuantitas kerja dari setiap pegawai maka langkah efektif adalah dengan memperhatikan jumlah, besar-kecil, ketepatan dan kecalancara serta keadilan dalam pemberian kompensasi baik berupa kompensasi langsung tidak langsung maupun kompensasi non-materi kesemuanya berdampak pada semangat kerja pegawai.

\section{Pengaruh Motivasi Kerja Terhadap Kinerja Pegawai Dinas Pertanian}

Setiap Instansi pemerintah maupun swasta membutuhkan pegawai yang cakap dan terampil, dan yang terpenting pegawai yang siap dan mau bekerja dan berkeinginan mencapai hasil kerja yang optimal (Agustina, 2005). Motivasi bisa menjadi salah satu penyebab dari rendahnya kinerja seseorang. Analisis mengenai performansi kerja akan berkaitan dengan dua faktor utama, yaitu kesediaan atau motivasi dari pegawai untuk bekerja, yang menimbulkan usaha pegawai, dan kemampuan pegawai untuk melaksanakannya. (Gomes, 2003).

Jika motivasi yang diberikan kepada pegawai kurang, maka kinerja yang diberikan juga akan rendah. Pegawai yang tetap semangat berkerja dan menaikan kinerja mereka sehingga kantor akan mencapai tujuan. Sasaran motivasi adalah untuk mencapai rasa memiliki tujuan bersama dengan memastikan bahwa sejauh mungkin keinginan dan kebutuhan organisasi serta keinginan dan kebutuhan para anggotanya berada dalam keadaan yang harmonis.

Menurut Wibowo (2014) motivasi adalah dorongan terhadap serangkaian proses prilaku manusia pada pencapaian tujuan. Sedangkan elemen yang terkandung dalam motivasi meliputi unsur membangkitkan, mengarahkan, menjaga, menunjukan intensitas, bersifat terus menerus dan adanya tujuan. Motivasi mempunyai dua bentuk dasar, yaitu buatan (extrinsic) dan hakiki (intrinsic), di dalam kinerja seseorang, organisasi memerlukan keduanya untuk membantu menaikan kinerja (extrinsic) maupun intrinsic), extrinsic adalah mengenai hal-hal apa yang akan perusahaan lakukan untuk memotivasi para pegawai sedangkan intrinsic adalah faktor-faktor atau penyebab dari dalam diri untuk memotivasi pegawai dengan tujuan tertentu. Karena setiap pegawai yang masuk pasti mempunyai motivasi kenapa mereka berkerja di instansi yang mereka pilih. Motivasi adalah sesuatu yang membuat orang bertindak atau berperilaku dalam cara-cara tertentu. 
Berkaitan dengan itu, diketahui motivasi kerja pegawai Dinas Pertanian Kota Bima tergolong tinggi ini menunjukkan semangat kerja, atau sesuatu yang mendorong pegawai, baik berasal dari dalam maupun dari luar diri seseorang, sehingga pegawai tersebut akan memiliki semangat, keinginan dan kemauan yang tinggi untuk melaksanakan tugasnya dengan baik selama menjalankan tugasnya sebagai pegawai Dinas Pertanian Kota Bima. Tingginya motivasi akan membuat pegawai menjadi semangat, giat dan fokus dalam menyelesaikan pekerjaan sehingga akan berdampak pada peningkatan kinerja sesuai dengan hasil pengujian hipotesis penelitian bahwa motivasi berpengaruh positif dan signifikan terhadap kinerja pegawai Dinas Pertanian Kota Bima. Hasil penelitian menudukung penelitian sebelumnya bahwa motivasi menjadi instrumen yang paling utama dalam

meningkatkan kepuasan kerja, dan kinerja pegawai (Rizal dan Idrus, 2014 dan Wenda Ros 2013).

Implikasi: Perubahan era yang semakin maju mendorong manusia ingin mencapai kehidupan yang lebih baik. Pencapaian tersebut ditunjukan melalui kinerja dan prestasi yang diberikan dalam bekerja. Sehingga dibutuhkan kemampuan atau kinerja dari seseorang yang lebih baik. Jika kinerja kurang baik maka dalam memajukan instansi akan dipastikan tidak baik oleh karena itu penting peningkatan motivasi kerja agar bisa mendapatkan dan menciptakan atau sumber daya manusia (SDM) yang berkualitas baik dalam sifat maupun kinerja. Latief (2012) mengemukakan bahwa dengan terbentuknya motivasi yang kuat, maka dapat membuahkan hasil atau kinerja yang baik sekaligus berkualitas dari pekerjaan yang telah dilakukan. Hal ini menunjukkan bahwa setiap peningkatan motivasi yang dimiliki oleh seseorang dalam melaksanakan pekerjaan akan memberikan peningkatan terhadap kinerjanya. Oleh karena itu motivasi kerja yang tinggi diperlukan organisasi untuk meningkatkan kinerja pegawai.

\section{Pengaruh Kepuasan Kerja Terhadap Kinerja Pegawai Dinas Pertanian}

Hasil penelitian bahwa kepuasan kerja pegawai Dinas Pertanian Kota Bima tergolong tinggi yang artinya perasaan selama menjadi pegawai yang bertugas pada

Dina Pertanian. Tingginya kepuasan kerja pegawai Dinas Pertanian mencerminkan perasaan dan sikap positif pegawai terhadap rekan kerja, peluang promosi dan kepuasan mereka terhadap kebijakan atasan yang akan membawa implikasi terhadap dirinya dan dinas. Kepuasan pegawai terhadap pekerjaannya akan termotivasinya untuk melaksanakan pekerjaannya, sebaliknya jika tidak puas dengan pekerjaannya ia tidak termotivasi untuk melaksanakan pekerjaannya dan kinerjanya rendah.

Kepuasan kerja merupakan kondisi menyenangkan atau secara emosional positif yang berasal dari penilaian seseorang atas pekerjaannya atau pengalaman kerjanya. Persepsi dapat berupa perasaan dan sikap orang terhadap pekerjaannya. Perasaan dan sikap dapat positif atau negatif. Jika seseorang bersikap positif terhadap pekerjaannya, maka ia puas terhadap pekerjaannya, sebaliknya, jika karyawan bersikap negatif terhadap pekerjaannya maka ia tidak puas terhadap pekerjaannya.

Tingginya kepuasan kerja dapat berdampak pada peningkatan kinerja. Affandi (2016) menyatakan bahwa kepuasan kerja menyebabkan peningkatan kinerja, sehingga pekerja yang puas akan lebih produktif dalam bekerja. Kinerja pegawai adalah keluaran yang dihasilkan oleh fungsi-fungsi atau dimensi pekerjaan atau profesi yang dilaksanakan oleh sumber daya manusia atau pegawai dalam waktu tertentu (Wirawan, 2013). Kinerja pegawai yang baik ditandai dengan adanya kualitas kerja yang baik dalam menyelesaikan setiap pekerjaan yang diberikan oleh pemimpin dengan tepat sesuai waktu yang ditentukan dan dapat mencapai setiap target yang telah ditetapkan. Mangkunegara (2011) mengatakan kinerja adalah prestasi kerja atau hasil kerja secara kualitas dan kuantitas yang 
dicapai oleh seorang pegawai dalam melaksanakan tugasnya sesuai dengan tanggung jawab yang diberikan kepadanya. Kinerja adalah kuantitas atau kualitas sesuatu yang dihasilkan atau jasa yang diberikan oleh seseorang yang melakukan pekerjaan (Luthans, 2011).

Kinerja Pegawai Dinas Pertanian Kota Bima berdasarkan hasil analisis deskriptif dikatahui tergolong tinggi ini disebakan karena tingginya kepuasan kerja pegawai terhadap tugas, rekan kerja, peluang promosi dan atasan karena berdasarkan hasil pengujian hipotesis penelitian kepuasan kerja berpengaruh positif dan signifikan terhadap kinerja pegawai. Pegawai merasa nyaman, dihargai, memiliki kesempatan mengembangkan diri, secara otomatis akan memusatkan perhatian dan menunjukkan performa kerja yang baik terhadap pekerjaan yang dilakukan. Hasil penelitian ini mendukung penelitian sebelumnya dilakukan

oleh Wijaya (2018) bahwa terdapat pengaruh kepuasan kerja terhadap kinerja karyawan CV Bukit Sanomas. Hasil penelitian juga mendukung hasil penelitian Rindiantika dan Susilo (2018) menyimpulkan bahwa kepuasan kerja adalah tolak ukur pegawai dalam meningkatkan kinerjanya.

Implikasi: baik atau tidaknya kenerja pegawai menjadi alasan maju mandurnya seuatu organisasi termasuk Dinas Pertanian. Oleh karena itu pencapaian kepuasan kerja merupakan kondisi emosional yang menyokong atau tidak dalam diri pegawai yang berhubungan dengan penilaian pegawai terhadap pekerjaan atau pengalaman kerja. Sebagai upaya peningkan kinerja pegawai, penting bagi dinas agar menerapkan kebijakan membangun harmonisasi hubungan sesama pegawai, peluang- peluang promosi yang adil dan akuntabilitas dan kebijakan atasan menjadi alasan puas dan tindaknya pegawai terhadap pekerjaan.

Selain itu, sejauh mana dinas mampu merealisasikan apa yang menjadi harapan dan tuntutan mereka, maka bekerja akan terasa memuaskan bagi pegawai (Saranya, 2014).
Setiap pegawai dipastikan memiliki kebutuhan dan harapan masing- masing, beberapa diantara mereka sadar akan hal tersebut, sedangkan yang lain tidak menyadarinya. Kebutuhan dan harapan tersebut yang menstimulasi perilaku pegawai. Jadi, kepuasan kerja merupakan representasi sikap dan penilaian pegawai atas pekerjaan dan pemenuhan atas harapan mereka.

\section{Pengaruh Doninan Kepuasan Kerja Terhadap Kinerja Pegawai}

Kepuasan kerja adalah suatu ungkapan perasaan atau sikap seseorang terhadap pekerjaannya, terhadap kesempatan promosi, hubungan dengan rekan kerja, pengawasan dan perasaan puas terhadap pekerjaan itu sendiri (Titisari, 2014:18). Kepuasan kerja menyangkut respon atau penilian pegawai mengenai keberadaan lingkungan kerja, kesejahteraan, atasan dan rekan kerja menjadi sumber puas dan tidak puanya pegawai dalam bekerja.

Kesemuanya itu berdasarkan hasil analisis stepwise bahwa kepuasan kerja memiliki pengaruh dominan terhadap kinerja pegawai Dinas Pertanian Kota Bima dibandingkan dengan variabel kompensasi dan motivasi kerja. Hasil penelitian mendukung hasil penelitian Komara dan Nelliwati (2014) kepuasan kerja memberikan pengaruh paling dominan terhadap kinerja pegawai RSUD Kota Bandung. Ketidak sesuai Antara kebutuhan dan ekspetasi pegawai merasa bahwa institusi tidak memberikan imbalan sesuai dengan ketetapan yang ada sehingga pegawai tidak termotivasi untuk melakukan yang terbaik untuk bekerja, sehingga timbul ketidakpuasan, dan bentuk ketidakpuasan tersebut diperlihatkan dalam perilaku kinerja yang rendah. Demikian juga dengan hasil penelitian Tiana (2017) kepuasa kerja memiliki pengaruh dominan dan signifikan terhadap kinerja karyawan di Warung Prasmanan AN-Nur Pare.

Implikasi: Berdasarkan hasil penelitian di atas maka dapat dipahami bahwa untuk memperbaiki kinerja pegawai dapat dilakukan dengan meningkatkan kesejahteraan pegawai 
melalui pemberian kompensasi karena akan dapat meningkatkan motivasi dan kepuasan kerja dan semuanya itu merupakan factor penentu tinggi rendahnya kinerja pegawai. Pemberian kompensasi bukan hanya ditinjau dari segi finansial tetapi juga menyangkut non finansial berupa keadilan dalam promosi jabatan, ketepan waktu dan kelancaran dalam pemberian kompensasi. Memotivasi pegawai juga dilakukan secara bersama melaui pemberian kompensasi serta juga akan meningkatkan kepuasan kerja pegawai. Puas terhadap rekan kerja, puas terhadap gaji dan puas terhadap atasan oleh karena itu perlu memperhatikan secara bersama-sama mengenai kompensasi dan motivasi kerja pegawai karena akan berdampak pada kepuasan kerja pegawai sementara kepuasan kerja merupakan factor yang paling dominan dalam mempengaruhi kinerja pegawai.

\section{KESIMPULAN}

Setelah melalui proses penelitian akhirnya peneliti dapat menarik kesimpulan penelitian sesuai dengan permasalah dalam penelirian yaitu:

1. Kompensasi Kerja memiliki pengaruh positif dan signifikan terhadap kinerja pegawai Dinas Pertanian Kota Bima. Pemberian kompensasi yang adil dan akuntabilitas serta sesuia dengan harapan dan kebutuhan akan meningkatkan kinerja pegawai.

2. Motivasi Kerja memiliki pengaruh positif dan ssignifikan terhadap kinerja pegawai Dinas Pertanian Kota Bima. Motivasi adalah gambaran dari etos dan semangat kerja yang akan meningkatkan kinerja pegawai. Semakin tinggi moitvasi kerja pegawai maka akan semakin tinggi kinerja demikian juga sebaliknya

3. Kepuasan kerja berpengaruh posotif dan signifikan terhadap kinerja pegawai Dinas Pertanian Kota Bima. Kepuasan kerja mencerminkan kepuasan pegawai terhadap lingkungan pekerjaan, gaji dan atas yang akan berdampak pada baik dan buruknya kinerja pegawai. Dengan kata lain semakin tinggi kepuasan kerja maka akan semakin tinggi kinerja pegawai.

4. Kepuasan Kerja memiliki pengaruh paling dominan terhadap kinerja pegawai

Dinas Pertanian Kota Bima. Artinya dalam upaya meningkatkan kinerja pegawai maka hal yang paling utama adalah perlu dan penting memperhatikan secara kepuasan kerja pegawai.

\section{Berdasarkan kesimpulan penelitian} di atas maka ada beberpa hal yang menjadi saran penelitian ini:

1. Bagi Kepala Daaerah agar memperhatikan kesejahteraan pegawai termasuk pegawai yang berstatus honorer karena kompensasi kerja akan mempengaruhi semangat kerja, dan kepuasan kerja yang pada gilirannya akan meningkatkan kinerja pegawai.

2. Bagi Pegawai agar dalam pelaksanaan tugas dan pengabdian sebagai pelayan public maka hendaknya memperbaiki kualitas kerja karena semakin tinggi kualitas pekerjaan akan berdampak pada peluang promosi dan kesempatan kerja serta kompensasi kerja.

3. Bagi penelitian agar mengkaji lebih dalam mengenai keadilan pemeberian kompensasi ditinjau dari pemenuhan kebutuhan sementara kebutuhan masingmasing pegawai pada umumnya berbeda yang disebabkan oleh keadaan yang berbeda pula. Perlu juga menkaji mengenai motivasi pegawai selain dengan cara pemberian kompenasi serta mengkaji secara mendalam factor-faktor yang mempengaruhi kepuasan kerja pegawai.

\section{DAFTAR PUSTAKA}

Abidin. 2013. Pengaruh Kepuasan, Motivasi dan Kedisiplinan Kerja Terhadap Kinerja Pegawai Di Lingkungan Kantor Wilayah Departemen Agama Provinsi Jawa Tengah. Tesis Program Pascasarjana Universitas Dian 
Nuswantoro

Semarang. http://eprints.dinus.ac.id/15056/1/JUR NAL_TESIS.pdf. Diakses 26 Okbtober 2019.

Aditya R. 2010. Pengaruh Gaya Kepempimpinan, Motivasi dan Disiplin Kerja terhadap

Kinerja Karyawan PT. Sinar Santosa Perkasa Banjarnegara.

Universitas Diponegoro. Semarang.

Affandi, P. 2016. Concept and Indicator Human Resources Management For Management Reaserch. Yogyakarta: CV Budi Utama.

Agustina, Ika, 2011. Faktor-Faktor Motivasi yang mempenggauhi Kinerja Karyawan pada PT Gaya Manunggal Kresitama 1-12. 1911-2025. Published by Canadian Center of Science and Education.

Gomes, F. Cardoso, 2003. Manajemen Sumber Daya Manusia. Cetakan Kedua, Penerbit Andi Offset: Yogyakarta

Handoko, T Hani. 2011. Manajemen Personalia dan Sumber daya Manusia, Edisi Kedua.Yogyakarta : BPFE.

Hasibuan, Malayu S.P. 2010. Manajemen Sumber Daya Manusia. Cetakan ke11.

Jakarta: PT.Bumi Aksara.

Iqbal N, Anwar S, Haider N. 2015.Effect of Leadership Style on Employee Performance.Arabian J Bus Manag Review 5: 146. doi:10.4172/2223-

5833.1000146.

Ilahi dan Mukzam. 2017. Pengaruh Kepuasan Kerja Terhadap Disiplin Kerja Dan Komitmen Organisasional (Studi Pada Karyawan PT.PLN (Persero) Distribusi Jawa Timur Area Malang. Jurnal Administrasi Bisnis (JAB)|Vol.
44

No.1

Maret

2017|administrasibisnis.studentjourna 1.ub.ac.id

Kadarisman. 2012. Manajemen Kompensasi. Jakarta: Rajawali Pers

Kasenda, R. 2013. Kompensasi dan Motivasi Pengaruhnya terhadap Kinerja Karyawan pada PT. Bangun Wenang Beverages Company Manado. Jurnal Ekonomi, Manajemen, Bisnis dan Akuntansi (EMBA), 1(3): 853-859.

Komara, A. T. dan Euis, N. 2014.Pengaruh Kompensasi, Motivasi dan Kepuasan Kerja terhadap Kinerja Pegawai Negeri Sipil (PNS) di Lingkungan Rumah Sakit Umum Daerah (RSUD) Kota Bandung. Jurnal Ekonomi, Bisnis \& Entrepreneurship, 8(2): 7385.

Kreitner, R. K., dan Angelo. 2005. Perilaku Organisasi. Terj. Suandy Erly. Salemba Empat, Jakarta.

Latief, B. 2012. Faktor- faktor yang Mempengaruhi Kinerja Karyawan PT. Mega Mulia Servindo di Makasar. Jurnal Manajemen dan Akuntansi , 1 (1), 61- 70 Lusiana, I., Shanti, K., dan Faula, A. (2015). Pengaruh Kompensasi Terhadap Kinerja

Karyawan Melalui Motivasi Kerja dan Kepuasan Kerja sebagai Variabel Intervening Menggunakan Structural Equation Modeling (SEM) (Studi Kasus di Divisi Produksi PT. XYZ). Jurnal Teknik Industri Universitas Sultan Ageng Tirtayasa, 3(1): 1-8.

Luthans, F. 2011. Organizational Behavior. New York: McGraw-hill.

Murgianto dan Sulasmi. 2016. The Effects Of Commitment, Competence, Work Satisfaction On Motivation, And Performance Of Employees At Integrate Service Office Of 
East Java. International Journal of Advanced Research (2016), Volume 3, Issue 378-396

Mangkunegara, A. P. 2011. Manajemen Sumber Daya Manusia Perusahaan. PT Remaja Rosdakarya, Bandung.

Meldona.2009. Manajemen Sumber Daya Manusia Perspektif Integratif. Cetakan ke-1 UIN Malang Press, Malang.Mas'ud, Fuad. 2009. Survai Diagnosis Organisasional, Konsep \& Aplikasi.

Semarang: Badan Penerbit Universitas Diponegoro

Mutmainah, H. 2013. Pengaruh Kompensasi, Pelatihan, dan Peran Supervisor terhadap Kinerja yang Dimediasi oleh Kepuasan Kerja pada Karyawan Paguyuban Batik Laweyan Surakarta. Jurnal Graduasi, 29:.1-20.

Murwansyah. 2012. Manajemen Sumber Daya Manusia. Edisi kedua. Bandung (ID): Penerbit Alfabeta

Murwansyah. (2012). Manajemen Sumber Daya Manusia. Edisi kedua. Bandung (ID): Penerbit Alfabeta

Munandar. (2016). Pengaruh Motivasi dan Kompensasi terhadap Kineja Guru Sekolah Swasta di Kota Malang. Tesis Tidak Dipublikasi Ilmu Manajemen Sumber Daya UM Malang.

Nurlaila.2010. Manajemen Sumber Daya Manusia. I. Penerbit LepKhair. Notoatmodjo S. 2009. Pengembangan Sumber Daya Manusia. Jakarta (ID): Penerbit Rineka Cipta

Odunlami, B. dan Oludele, M. 2014. Compensation Management and Employees Performance in the Manufacturing Sector, A Case Study of a Reputable Organization in the
Food and Beverage Industry. International Journal of Managerial Studies and Research (IJMSR), 2(9):.108-117.

Prawironegoro dan Tjatjuk, S. 2011. Manajemen Sumber Daya Manusia Abad 21. Nusantara Consulting, Jakarta.

Rizal dan Idrus. 2014. Effect of Compensation on Motivation, Organizational Commitment and Employee Performance (Studies at Local Revenue Management in Kendari City). International Journal of Business and Management Invention. ISSN (Online): 2319 - 8028, ISSN (Print): $2319-801 \mathrm{X}$ www. ijbmi. org Volume 3 Issue 2 February 2014. PP. 64-79.

Rijalu dan Zewude (2014) The effect of compensation on employees motivation: In Jimma University academic staff. Basic Research Journal of Business Management and Accounts ISSN 2315-6899 Vol. 3(2) pp. 17-27 February 2014.http//www.basicresearchjournal s.org.

Revenio Jalagat. 2016. Job Performance, Job Satisfaction, and Motivation: A Critical Review of their Relationship. International Journal of Advances in Management and Economics Available online at: www.managementjournal.info.

Rindiantika dan Heru.2018. Pengaruh Kepuasan Kerja Terhadap Kinerja Karyawan Dengan Organizational Citizenship Behavior Sebagai Variabel Intervening (Studi pada Karyawan PTPN X - Unit Usaha Pabrik Gula Modjopanggoong Tulungagung). Jurnal Administrasi Bisnis (JAB)|Vol. 64 No. 1 November 
2018

administrasibisnis.studentjournal.ub.a c.id.

Rivai, V. dan Mulyadi, D. (2009).Kepemimpinan dan Perilaku Organisasi.Jakarta : Raja Grafindo Persada.

Rizal dan Idrus. 2014. Effect of Compensation on Motivation, Organizational Commitment and Employee Performance (Studies at Local Revenue Management in Kendari City). International Journal of Business and Management Invention. ISSN (Online): 2319 - 8028, ISSN (Print): $2319-801 \mathrm{X}$ www. ijbmi. org Volume 3 Issue 2 February 2014. PP. 64-79.

Robbins dan Judge.2008. Perilaku Organisasi. PT Indeks, Kelompok Gramedia, Jakarta. Riani, A. L. 2013. Manajemen Sumber Daya Manusia Masa Kini. Graha Ilmu, Yogyakarta. Rindiantika dan Susilo. 2018. Pengaruh Kepuasan Kerja Terhadap Kinerja Karyawan Dengan

Organizational Citizenship Behavior Sebagai Variabel Intervening (Studi pada Karyawan PTPN X - Unit Usaha Pabrik Gula Modjopanggoong Tulungagung). Jurnal Administrasi Bisnis (JAB)|Vol. 64 No. 1 November 2018.

Riyadi, S. 2011. Pengaruh Kompensasi Finansial, Gaya Kepemimpinan, dan

Motivasi KerjaTerhadap Kinerja Karyawan pada Perusahaan Manufaktur di Jawa Timur.

JurnalManajemen dan Kewirausahaan, 13(1): 40-45.

Santoso dan Singgih.2013. Buku Latihan SPSS Statistik Parametrik. Jakarta: Elex Media Komputindo.
Saranya, Kamala. 2014. Influence of Job Satisfaction on Employee's Performance - A General Perspective. Vol. 2 (2).

Sugiyono. 2014. Metode Penelitian Kuantitatif, Kualitatif dan $\mathrm{R}$ dan D.Bandung: Alfabeta. Suhendra dan Murdiyah, H. 2006.Manajemen Sumber Daya Manusia. UIN Jakarta Press, Jakarta.

Saranya, K. 2014. Influence of Job Satisfaction on Employee's Performance - A General Perspective. Vol. 2 (2).

Saranya, Kamala. 2014. Influence of Job Satisfaction on Employee's Performance - A General Perspective. Vol. 2 (2).

Supatmi, M. E., Umar, N., dan Hamidah, N. U. (2013).Pengaruh Pelatihan, Kompensasi terhadap Kepuasan Kerja Karyawan dan Kinerja Karyawan. Jurnal Profit, 7 (1):25-37.

Sutrisno, E. 2009. Manajemen Sumber Daya Manusia, cetakan ke-1. Kencana Prenada mediaGroup, Jakarta.

Sutrisno, Edy.2010. Manajemen Sumber Daya Manusia. Jakarta: Kencana Prenada Media Group.

Suwati, Yuli. 2013. Pengaruh Kompensasi dan Motivasi Kerja terhadap Kinerja Karyawan pada PT. Tuntas Hijau Samarinda. E-jurnal Ilmu Administrasi Bisnis, Volume 1, Nomor 1. 2013: 41-55.

Sanuddin dan WIdjojo. 2013 Pengaruh Kepuasan Kerja dan Motivasi Kerja Terhadap kinerja karyawan pt. Semen Tonasa. MODUS Vol. 25 (2), 2013

Uno.HB. 2011. Teori Motivasi dan Pengukurannya: Analisis di Bidang Pendidikan. Jakarta:

Bumi aksara 
Titisari,Purnami. 2014.Peranan Organizational Citizenship Behavior (OCB): Dalam

Meningkatkan Kinerja Karyawan. Jakarta: Mitra Wacana Media.

Tiana. 2017. Pengaruh Kompensasi, Motivasi, dan Kepuasan Kerja terhadap Kinerja Karyawan Warung Prasmanan ANNur Pare. Simki-Economic Vol. 01 No. 04 Tahun 2017. http://simki.unpkediri.ac.id/mahasisw a/file_artikel/2017/61d619b5f7019b6 095 dd089fa2b2e04e.pdf

Titisari, Purnami. 2014. Peranan Organizational Citizenship Behavior (OCB): Dalam Meningkatkan Kinerja Karyawan. Jakarta: Mitra Wacana Media Tuan, Luu Trong. 2011. Convergence of Antecedents on Work Motivation and Work Outcomes. Mediterranean Journal of Social Sciences. Vol.2.No.2.pp:54-56.

Pitasari dan Perdhana. 2018. Kepuasan Kerja Karyawan : Studi Literatur. Diponegoro Journal Of MANAGEMENTVOLUME 7, Nomor 4, Tahun 2018, Halaman 1-11.

Pratama dan Hakam. 2015. Pengaruh Kompensasi Terhadap Kinerja Karyawan (

Studi Pada Karyawan PT. Asuransi Jiwasraya persero regional office Malang). Jurnal Administrasi Bisnis (JAB)|Vol. 25 No. 1 Agustus 2018.

Wahab, R.B. 2012. Pengaruh Kepuasan Kerja Dan Motivasi Kerja terhadap Kinerja Karyawan PT.Bank Mandiri. Fakultas Ekonomi dan Bisnis Universitas Hasanuddin. Wardoyo dan Priyono. 2015. The Influence of Motivation and Discipline Work against

Employee Work Productivity Tona'an Markets. Review of European Studies; Vol. 7, No. 12; 2015. ISSN 1918-7173
E-ISSN 1918-7181. Published by Canadian Center of Science and Education.

Wenda Ros. 2013. The Relationship Between Employee Motivation, Job Satisfaction And Corporate Culture. SA Journal of Industrial Psychology.Vol. 34 No. 1 pp.

54 - 63.http://www.sajip.co.za Wexley, K. N. dan Yuki, G. A. 2005.Perilaku Organisasi dan Psikologi Personali terj.Shobaruddin M. PT Asdi Mahasatya, Jakarta.

Wijaya. 2018. Pengaruh Kepuasan Kerja Terhadap Kinerja Karyawan CV Bukit Sanomas. AGORA Vol. 6, No. 2 (2018). https://media.neliti.com/media/public ations/287109-pengaruh-kepuasankerja-terhadap-kinerja-d6b6fa9c.pdf

Wirawan. 2013. Kepemimpinan: Teori, Psikologi, Perilaku Organisasi, Aplikasi dan

Penelitian. Jakarta: PT. Raja Grafindo Persada

Zaidun dan Duhima. 2013. Pengaruh Motivasi Kerja Dan Budaya Organisasi Terhadap Kinerja Karyawan. Jurnal Intelektual Dinamis dan Progres Palembang, Volume 4 No 22013. 